\title{
A comparison of the clinical features of depression in hiv-positive and hiv-negative patients in Uganda
}

\author{
DH Akena, S Musisi, E Kinyanda
}

Department of Psychiatry, Makerere University College of Health Sciences, Kampala, Uganda

\begin{abstract}
Objective: Depressive illness is the most common psychiatric disorder in HIV/AIDS with prevalence 2 to 3 times higher than the general population. It's still questionable whether HIV related depression is clinically different from depression in HIV-negative populations, a fact that could have treatment implications. This study compared the clinical features of major depression between HIV-Positive and HIV-negative patients with a view to intervention strategies. Method: A comparative, descriptive, cross-sectional study was carried out on 64 HIV-Positive depressed patients and 66 HIV-negative depressed patients in Butabika and Mulago hospitals. They were compared along the parameters of clinical features of depression, physical examination and laboratory findings. Pair wise comparisons, logistic regression and Multivariate analysis were done for the two groups on a number of variables. Results: Compared to HIV-Negative patients, HIV-Positive patients were more likely to be widowed; older ( $\geq 30 y e a r s)$,

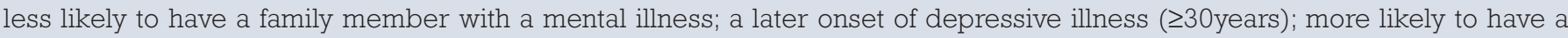
medical illness and taking medication before onset of depressive, symptomatically compared to HIV-Negative patients, HIV-Positive patients were more critical of themselves ; had significantly more problems making decisions ; had poorer sleep; felt more easily tired; more appetite changes; more cognitive impairment. Low CD4 counts were not significantly associated with depression, but HIV related depression was more likely to occur in stages II and III illness. Conclusion: These findings show that the clinical and associated features of depression differ between HIV-Positive and HIV-Negative patients, thus requiring different management approaches and further studies related to HIV-related depression.
\end{abstract}

Key words: Clinical features; Depression; HIV/AIDS; Uganda

Received: 20-1 1-2008

Accepted: 04-03-2009

\section{Introduction}

HIV/AIDS is a global health problem. In the last 2 decades it has claimed nearly 30 million lives. ${ }^{1}$ About 40 million people are now living with HIV/AIDS and Sub-Saharan Africa remains by far the worst affected region in the world with a continental prevalence of around 7.4\% $\%^{2}$; two thirds (64\%) of all people living with HIV/AIDS are in sub-Saharan Africa. ${ }^{2}$

A significant number of HIV infected people develop mental health problems, which not only impinge on their

\section{Correspondence:}

Dr DH Akena

Department of Psychiatry, Makerere University College of Health

Sciences, Kampala, Uganda

email: akenadickens@yahoo.co.uk quality of life but also often adversely impact on their HIV/AIDS treatment, especially compliance with treatment regimens. ${ }^{3}$ Among the numerous psychiatric disorders found in HIV/AIDS patients, depression is the most common with rates 2-3 times higher than in the general population. 4,5

Despite its high prevalence, major depression remains under-diagnosed and undertreated in patients with HIV/AIDS due to rationalization that depression is a logical and normal outcome of HIV/AIDS; misconceptions such as depression due to 'organic' conditions such as HIV/AIDS is unlikely to respond to antidepressant therapies; and similarities of the somatic symptoms that accompany major depression - such as sleep disturbance, fatigue, decreased appetite - with those associated with HIV disease. ${ }^{6}$

People with HIV are at increased risk for depression for a variety of reasons including stigma and discrimination, the 
knowledge that they are likely to die prematurely of AIDS and the direct and indirect effects of HIV on the brain. ${ }^{7,8}$ Depressive symptoms in HIV/AIDS have been associated with disease progression ${ }^{6,9}$, suggesting that it may be a manifestation of the HIV disease process itself or advanced immunosupression. $6,10,11$

Suicide is frequently observed among HIV patients with its prevalence to ranging from 7 to 36 times the rate in demographically similar control populations. ${ }^{12}$ Furthermore, untreated depression in HIV/AIDS often leads to poor or noncompliance with any treatment given, including ARVs, which can lead to development of resistant strains of the HIV virus. ${ }^{13}$

There is paucity of data from sub-Saharan Africa, and Uganda in particular, related to the extent of depression in HIV/AIDS. ${ }^{14}$ Anecdotal evidence suggests that only a small number of HIV/AIDS patients receive any mental healthcare. ${ }^{14}$ It is also not clear as to whether the depression of HIV/AIDS is clinically different from the primary depressive disorder as seen in HIV-negative patients. Research undertaken in developed countries has demonstrated that effective treatment of depression in HIV/AIDS patients improves the patient's outcome, delays progression of HIV to AIDS and leads to better compliance with any HIV/AIDS treatment regimens. 12,15,16

This study therefore aimed to investigate and compare clinical features of depression in HIV-positive patients and HIV-negative patients with a view to delineate HIV-related depression as a clear clinical entity with treatment implications. For the purposes of this study, a depressed patient was defined as a patient who, at the time of the study, had signs and symptoms of a major depressive episode as defined in the DSM-IV-TR. ${ }^{17}$

\section{Methods}

This was a cross sectional, descriptive, comparative study conducted at the mental health units of Mulago general hospital and Butabika psychiatric hospital between June August 2007. Butabika is the national referral and teaching psychiatric hospital in Kampala city, while the Mulago Hospital Mental Health Unit is a 40 bed-unit located within the 1500 bed Mulago General and Teaching Hospital in Kampala city, Uganda.

All the study patients met criteria for DSM-IV-TR major depression, were above 18 years and gave informed consent. Those with other active physical illnesses and alcohol misuse were excluded from the study. An HIV test was done after pre-test counseling. Two unmatched groups of depressed patients were consecutively and proportionately recruited (HIV-positive and HIV-negative), in the ratio of Butabika: Mulago of 4:1 (in proportion to the size of the mental health units) till the sample size was obtained.

Psychiatrists attached to the units where the patients were accessing care diagnosed the depression. The diagnosis of depression was then confirmed using the Mini International Neuropsychiatric Interview (MINI) and the depressive symptoms were rated using the Beck Depression Inventory (BDI). Cognitive functioning was assessed using the Mini Mental State Examination (MMSE). A standardized sociodemographic questionnaire was administered, the patients were physically examined and a blood test done for diagnosis of HIV after pretest and then later post test counseling. Other blood tests included CD4 levels, Toxoplasmosis titers, serum CRAG, FBC, and TPHA. The WHO clinical staging of HIV/AIDS was done for those who were HIV-positive.

All patients gave informed consent. Institutional permission to carry out the study was sought from all the relevant hospital and university authorities as well as the Uganda National Council of Science and Technology (UNCST).

Statistical analysis was carried out using the computer programme Statistical Package for Social Scientists (SPSS), version 11.5. Univariate analysis was used to describe the characteristics of the respondents and the two groups were compared using univariate analysis. Variables that had significant differences at univariate analysis between the two groups were then included in a multivariate logistic regression model to determine independent associations.

\section{Results}

During the study period from June to August 2007, 1156 patients accessed care at the 2 study sites; 180 patients were diagnosed with depression, thus giving a prevalence of depression of $15.6 \%$ among patients attending psychiatric services. 150 of these (74.2\%) met the study criteria for major depression, while 12 patients were excluded because of having alcohol use disorders and active medical illness. 138(86\%) consented to the study; eight (6.2\%) patients out of the 138 had incomplete data and so only 130 were finally analysed.

Of the 130 evaluable study participants, 66 (50.7\%) patients were HIV-negative and 64(49.3\%) were HIV-positive. The mean age of the patients was 31 years $(\mathrm{SD}= \pm 8.5$ years) and $68(52 \%)$ of the patients were aged $18-30$ years. The two groups (HIV-positive and HIV-negative) were then compared.

Compared to the HIV-negative patients, HIV-positive patients were less likely to have never been married $(p=<0.001)$ and were more likely to have been widowed $(p=<0.003)$. They were also generally older ( $\geq 30$ years, $\mathrm{p}=0.009)$ and were more likely to be unemployed $(\mathrm{p}=0.006)$. There were no statistically significant differences on the other sociodemographic parameters. (Table I)

Compared to HIV-negative patients, HIV-positive patients had onset of depression at a significantly older age of $>$ 30years ( $p=0.003)$ and they were less likely to have a family member with a mental illness $(p=0.032)$ and to have lost their sexual partners before admission to hospital. The majority of the widows/widowers was found in the HIV/AIDS group $(\mathrm{P}=0.040)$. The HIV-positive patients were also more likely to have been taking non- prescribed, over the counter medications, majority of which were antibiotics and antimalarials which they had bought from near- by pharmacies and drug shops before onset of their depressive symptoms $(\mathrm{p}=0.001)$. They were also more likely to have had a medical illness before their depressive symptoms began $(p<0.001)$. The majority of HIV-positive patients and HIV-negative patients had had past depressive episodes but there was no statistically significant difference between the two groups on this parameter $(p=0.219)$, nor on the source of referral. (Table II) 
Table I: Sociodemographic characteristics of the study patients, by HIV status.

\begin{tabular}{|c|c|c|c|c|c|}
\hline Characteristic & HIV-Positive N=64 n(\%) & HIV-Negative $N=66 n(\%)$ & $x^{2}$ & OR $(95 \% \mathrm{Cl})$ & $P$-Value \\
\hline $\begin{array}{l}\text { Gender } \\
\text { Male } \\
\text { Female }\end{array}$ & $\begin{array}{l}14(21.9 \%) \\
50(78.1 \%)\end{array}$ & $\begin{array}{l}14(21.2 \%) \\
52(78.8 \%)\end{array}$ & 0.01 & $1.04(0.45-2.40)$ & 0.927 \\
\hline $\begin{array}{l}\text { Age Mean (SD) } \\
\text { Range } 18-59 \text { yrs. }\end{array}$ & $32(6.5)$ & $27(8.5)$ & 0.07 & $1.02(0.55-0.99)$ & 0.088 \\
\hline $\begin{array}{l}\text { Age categories } \\
18-30 \text { years } \\
>30 \text { years }\end{array}$ & $\begin{array}{l}26(40.6 \%) \\
38(59.4 \%)\end{array}$ & $\begin{array}{l}42(63.6 \%) \\
24(36.4 \%)\end{array}$ & 6.89 & $0.39(0.19-0.79)$ & 0.009 \\
\hline $\begin{array}{l}\text { Marital status } \\
\text { Married/Cohabiting } \\
\text { Never married } \\
\text { Widowed } \\
\text { Separated/divorced }\end{array}$ & $\begin{array}{l}24(37.5 \%) \\
10(15.6 \%) \\
17(26.6 \%) \\
13(20.3 \%)\end{array}$ & $\begin{array}{l}19(28.8 \%) \\
31(47.0 \%) \\
4(6.1 \%) \\
12(18.2 \%)\end{array}$ & $\begin{array}{l}0.09 \\
14.78 \\
10.08 \\
0.09\end{array}$ & $\begin{array}{l}1.12(0.52-2.41) \\
0.20(0.09-0.48) \\
5.60(1.76-17.76) \\
1.14(0.47-2.74)\end{array}$ & $\begin{array}{l}0.087 \\
<0.001 \\
0.003 \\
0.758\end{array}$ \\
\hline $\begin{array}{l}\text { Education } \\
\text { No education } \\
\text { Primary } \\
\text { Secondary }\end{array}$ & $\begin{array}{l}4(6.3 \%) \\
33(51.6 \%) \\
27(42.2 \%)\end{array}$ & $\begin{array}{l}4(6.1 \%) \\
29(43.9 \%) \\
33(50 \%)\end{array}$ & $\begin{array}{l}0.01 \\
0.75 \\
0.05\end{array}$ & $\begin{array}{l}1.03(0.24-4.32) \\
1.35(0.68-2.70) \\
1.14(0.36-3.61)\end{array}$ & $\begin{array}{l}0.964 \\
0.385 \\
0.815\end{array}$ \\
\hline $\begin{array}{l}\text { Religion } \\
\text { Catholic } \\
\text { Anglican } \\
\text { Moslem } \\
\text { Other }\end{array}$ & $\begin{array}{l}23(35.9 \%) \\
18(28.1 \%) \\
8(12.5 \%) \\
15(23.4 \%)\end{array}$ & $\begin{array}{l}22(33.3 \%) \\
10(15.1 \%) \\
9(13.6 \%) \\
25(37.8 \%)\end{array}$ & 0.06 & $0.99(0.58-0.88)$ & 0.870 \\
\hline $\begin{array}{l}\text { Occupation } \\
\text { Employed } \\
\text { Peasant farmer } \\
\text { Unemployed } \\
\text { Student }\end{array}$ & $\begin{array}{l}26(40.6 \%) \\
9(14.0 \%) \\
25(39 \%) \\
4(6.2 \%)\end{array}$ & $\begin{array}{l}27(40.9 \%) \\
18(27.3 \%) \\
12(18.2 \%) \\
9(13.6 \%)\end{array}$ & $\begin{array}{l}5.00 \\
0.45 \\
3.00 \\
2.00\end{array}$ & $\begin{array}{l}1.12(0.52-2.41) \\
1.01(0.42-1.80) \\
0.35(0.63-1.50) \\
1.35(3.63-13.50)\end{array}$ & $\begin{array}{l}0.689 \\
0.095 \\
0.006 \\
0.092\end{array}$ \\
\hline
\end{tabular}

Table II: General characteristics of the study patients, by HIV status.

\begin{tabular}{|c|c|c|c|c|c|}
\hline Characteristic & HIV-Positive N=64 n(\%) & HIV-Negative $N=66 n(\%)$ & $x^{2}$ & OR (95\%Cl) & P-Value \\
\hline $\begin{array}{l}\text { Age of onset } \\
18-30 \\
\geq 30 \text { Years }\end{array}$ & $\begin{array}{l}38(59.4 \%) \\
26(40.6 \%)\end{array}$ & $\begin{array}{l}51(77.3 \%) \\
15(22.7 \%)\end{array}$ & 4.82 & $0.43(0.20-0.92)$ & 0.030 \\
\hline $\begin{array}{l}\text { Family member with } \\
\text { mental illness }\end{array}$ & $21(32.8 \%)$ & $34(51.5 \%)$ & 4.65 & $0.46(0.22-0.93)$ & 0.032 \\
\hline Currently first episode & $26(40.6 \%)$ & 20(30.3\%) & 1.51 & $1.57(0.76-3.24)$ & 0.219 \\
\hline $\begin{array}{l}\text { Taking medicine before } \\
\text { depressive symptoms }\end{array}$ & $18(28.1 \%)$ & $4(6.1 \%)$ & 11.25 & $6.06(1.92-19.12)$ & 0.002 \\
\hline $\begin{array}{l}\text { Medical illness before } \\
\text { depressive symptoms }\end{array}$ & $30(46.9 \%)$ & $4(6.1 \%)$ & 28.02 & $13.67(4.44-42.08)$ & $<0.001$ \\
\hline $\begin{array}{l}\text { Source of referral } \\
\text {-Relatives } \\
\text {-Hospital / clinics }\end{array}$ & $\begin{array}{l}40(62.5 \%) \\
24(37.5 \%)\end{array}$ & $\begin{array}{l}36(54.5 \%) \\
30(45.5 \%)\end{array}$ & $\begin{array}{l}3.98 \\
0.98\end{array}$ & $\begin{array}{l}2.34(0.85-0.99) \\
1.56(.056-0.98)\end{array}$ & $\begin{array}{l}0.567 \\
0.765\end{array}$ \\
\hline $\begin{array}{l}\text { Lost a sexual partner } \\
\text { before admission }\end{array}$ & $17(26.6 \%)$ & $1(1.5 \%)$ & 9.00 & $5.60(1.76-17.76)$ & 0.040 \\
\hline
\end{tabular}




\section{Clinical characteristics}

The symptoms elicited with the MINI showed that both groups had considerable appetite changes and sleep problems. Compared to the HIV-negative group, HIVpositive patients had significantly less appetite changes $(p=0.017)$ but more sleep problems $(p=0.020)$. There were no statistically significant differences in the two groups along the other depressive clinical symptoms.(Table III)

\section{BDI clinical characteristics}

The Beck Depression Inventory (BDI) was used to rate the severity of the depression in the two groups. The mean BDI score was 29.63 (SD 9.088) in the HIV positive patients and 29.30 (SD 9.740) in the HIV negative patients showing no statistically significant differences $(p=0.641)$ in the total scores of the BDI between the 2 groups or in the various categories of severity of depression. (Table IV)

The Majority of the patients in both groups $121(93.1 \%)$ had mild to moderate depression. There were no significant statistical differences on the BDI severity categories between the two groups. The BDI subscale scores were then analyzed for differences on individual symptoms of depression in the two groups. (Table V)

HIV-positive patients were significantly more likely to be self critical of themselves ( $p=0.014)$, to put off making decisions making $(p=0.050)$, to have poor sleep $(p=0.054)$, and got more tired than usual $(p=0.004)$. It should be noted that these differences were in the core symptoms of depression.

\section{Immunological functioning}

Mean CD4 in HIV-positive patients was 271.77

$(\mathrm{SD}=162.410)$ and among HIV negative patients it was 986.67(SD=108.321). The distribution of BDI scores in the HIV-positive by the CD4+ cell counts correlated with the severity of depression and the severity of immune suppression. The majority of the HIV-positive patients 60(93.8\%) had mild to moderate depression as rated by the BDI, and the majority of these patients 44(68.8\%) also had CD4+ ranges from 200-500. There was no statistically significant association between CD4+ counts and severity of depression $(p=0.656)$. When the CD4+ was categorized as $<200$ and $\geq 200$, still there was no significant statistical associations between CD4+ level and severity of depression $(p=0.153)$. (Table VI)

The WHO HIV-disease stage was then correlated to the degree of depression. Most of the HIV-positive respondents had mild to moderate depression 58(90.1\%), and the majority were also in stage II and III 51 (79.7\%). there was however no statistical significant association between the WHO clinical stage and severity of depression as noted by the BDI scores $(p=0.231$ ) (Table VII).

The results regarding cognitive function using the Mini Mental State Examinations (MMSE) showed that compared to HIV-negative patients, HIV-positive patients were statistically significantly more likely to be cognitively impaired ( $p=0.029$ ) (Table VIII). However there was no statistically significant difference between the 2 groups in the 3 degrees of severity of cognitive impairment. A

\section{Table III: Depressive clinical symptoms derived with the MINI, by HIV status.}

\begin{tabular}{|l|l|l|l|l|l|}
\hline Variable & HIV-Positive N=64 n(\%) & HIV-Negative N=66 n(\%) & X2 & OR (Cl) & $P$-value \\
\hline Depressed mood & $60(93.8 \%)$ & $61(92.4 \%)$ & 0.08 & $1.23(0.31-4.80)$ & 0.766 \\
\hline Loss of interest & $54(84.4 \%)$ & $60(90.9 \%)$ & 1.28 & $0.54(0.18-1.58)$ & 0.256 \\
\hline Appetite change & $53(82.8 \%)$ & $64(97.0 \%)$ & 7.23 & $0.15(0.03-0.70)$ & 0.017 \\
\hline Sleep problems & $60(93.3 \%)$ & $52(78.8 \%)$ & 6.09 & $4.03(1.25-13.03)$ & 0.020 \\
\hline Slowed down & $53(82.2 \%)$ & $54(81.8 \%)$ & 0.02 & $1.07(0.43-2.63)$ & 0.882 \\
\hline Feeling tired & $51(79.9 \%)$ & $59(89.4 \%)$ & 2.35 & $0.46(0.17-1.25)$ & 0.131 \\
\hline Feeling worthless & $33(51.6 \%)$ & $43(65.2 \%)$ & 2.47 & $0.56(0.28-1.15)$ & 0.117 \\
\hline Difficulty concentrating & $53(82.2 \%)$ & $52(78.8 \%)$ & 0.33 & $1.29(0.53-3.12)$ & 0.561 \\
\hline Suicidal ideation & $46(71.9 \%)$ & $46(69.7 \%)$ & 0.07 & $1.11(0.52-2.36)$ \\
\hline
\end{tabular}

\section{Table IV: BDI scores by HIV status.}

\begin{tabular}{|l|l|l|l|l|l|}
\hline BDI Score & HIV-positive n(\%) & HIV-Negative n (\%) & $X^{2}$ & OR (Cl) & P-value \\
\hline$<14$ & 2 & 2 & N/A & N/A & N/A \\
Mild 14-30 & 35 & 36 & 0.09 & $1.22(1.00-3.45)$ & 0.980 \\
Moderate 31-45 & 25 & 25 & 0.01 & $1.02(0.50-2.04)$ & 0.761 \\
Severe 46-63 & 2 & 1 & N/A & N/A & N/A \\
\hline
\end{tabular}




\begin{tabular}{|c|c|c|c|c|c|}
\hline BDI Sub-scale & $H I V$-positive $N=64 n(\%)$ & HIV-Negative $N=66 n(\%)$ & $x^{2}$ & OR $(95 \% \mathrm{Cl})$ & P-Value \\
\hline $\begin{array}{l}\text { Feeling sad } \\
\text { Feeling Discouraged }\end{array}$ & $\begin{array}{l}48(75.0 \%) \\
47(73.4 \%)\end{array}$ & $\begin{array}{l}55(83.3 \%) \\
51(77.3 \%)\end{array}$ & $\begin{array}{l}1.37 \\
0.25\end{array}$ & $\begin{array}{l}1.66(0.71-0.93) \\
1.23(0.55-2.73)\end{array}$ & $\begin{array}{l}0.242 \\
0.612\end{array}$ \\
\hline $\begin{array}{l}\text { Feeling a failure. } \\
\text { No satisfaction with life }\end{array}$ & $\begin{array}{l}38(59.4 \%) \\
46(71.9 \%)\end{array}$ & $\begin{array}{l}45(68.2 \%) \\
53(80.3 \%)\end{array}$ & $\begin{array}{l}1.09 \\
1.27\end{array}$ & $\begin{array}{l}1.46(0.71-3.01) \\
1.59(0.70-3.60)\end{array}$ & $\begin{array}{l}0.297 \\
0.262\end{array}$ \\
\hline $\begin{array}{l}\text { Guilt } \\
\text { Need for punishment }\end{array}$ & $\begin{array}{l}26(40.6 \%) \\
29(45.3 \%)\end{array}$ & $\begin{array}{l}27(40.9 \%) \\
33(50.0 \%)\end{array}$ & $\begin{array}{l}0.01 \\
0.28\end{array}$ & $\begin{array}{l}1.01(0.50-2.03) \\
1.20(0.60-2.40)\end{array}$ & $\begin{array}{l}0.974 \\
0.593\end{array}$ \\
\hline $\begin{array}{l}\text { Disappointed in life } \\
\text { Critical of self }\end{array}$ & $\begin{array}{l}43(67.2 \%) \\
23(35.9 \%)\end{array}$ & $\begin{array}{l}50(75.8 \%) \\
38(57.6 \%)\end{array}$ & $\begin{array}{l}1.17 \\
6.10\end{array}$ & $\begin{array}{l}1.52(0.70-3.28) \\
2.41(1.19-4.90)\end{array}$ & $\begin{array}{l}0.280 \\
0.014\end{array}$ \\
\hline $\begin{array}{l}\text { Suicidal thoughts } \\
\text { Crying }\end{array}$ & $\begin{array}{l}26(40.6 \%) \\
5(7.8 \%)\end{array}$ & $\begin{array}{l}22(33.3 \%) \\
12(18.2 \%)\end{array}$ & $\begin{array}{l}0.74 \\
3.07\end{array}$ & $\begin{array}{l}0.73(0.35-1.49) \\
2.622(0.86-7.93)\end{array}$ & $\begin{array}{l}0.390 \\
0.088\end{array}$ \\
\hline $\begin{array}{l}\text { Irritated } \\
\text { Loss of interest }\end{array}$ & $\begin{array}{l}18(28.1 \%) \\
35(54.7 \%)\end{array}$ & $\begin{array}{l}23(34.8 \%) \\
46(69.7 \%)\end{array}$ & $\begin{array}{l}0.68 \\
3.79\end{array}$ & $\begin{array}{l}1.36(0.65-2.87) \\
0.96(0.26-3.51)\end{array}$ & $\begin{array}{l}0.410 \\
0.150\end{array}$ \\
\hline $\begin{array}{l}\text { Puts off decision making } \\
\text { Worried about looks }\end{array}$ & $\begin{array}{l}25(39.1 \%) \\
21(32.8 \%)\end{array}$ & $\begin{array}{l}39(59.1 \%) \\
30(45.5 \%)\end{array}$ & $\begin{array}{l}5.89 \\
2.17\end{array}$ & $\begin{array}{l}\mathrm{N} / \mathrm{A} \\
1.70(0.83-3.47)\end{array}$ & $\begin{array}{l}0.050 \\
0.141\end{array}$ \\
\hline $\begin{array}{l}\text { Extra effort to do work } \\
\text { Does not sleep as well }\end{array}$ & $\begin{array}{l}45(70.3 \%) \\
42(65.6 \%)\end{array}$ & $\begin{array}{l}(74.2 \%) \\
55(83.3 \%)\end{array}$ & $\begin{array}{l}1.16 \\
5.83\end{array}$ & $\begin{array}{l}\text { N/A } \\
\text { N/A }\end{array}$ & $\begin{array}{l}0.558 \\
0.050\end{array}$ \\
\hline $\begin{array}{l}\text { Get more tired } \\
\text { Poor appetite }\end{array}$ & $\begin{array}{l}39(60.9 \%) \\
8(12.5 \%)\end{array}$ & $\begin{array}{l}55(83.3 \%) \\
9(13.6 \%)\end{array}$ & $\begin{array}{l}8.13 \\
0.03\end{array}$ & $\begin{array}{l}3.20(1.41-7.27) \\
1.10(0.39-3.06)\end{array}$ & $\begin{array}{l}0.005 \\
0.848\end{array}$ \\
\hline $\begin{array}{l}\text { Weight loss } \\
\text { Worried about health }\end{array}$ & $\begin{array}{l}30(46.9 \%) \\
18(28.1 \%)\end{array}$ & $\begin{array}{l}36(54.5 \%) \\
13(19.7 \%)\end{array}$ & $\begin{array}{l}0.76 \\
1.27\end{array}$ & $\begin{array}{l}1.36(0.68-2.71) \\
0.62(0.27-1.41)\end{array}$ & $\begin{array}{l}0.382 \\
0.262\end{array}$ \\
\hline Lost interest in sex & $14(21.9 \%)$ & $11(16.7 \%)$ & 0.56 & $0.71(0.29-1.71)$ & 0.452 \\
\hline
\end{tabular}

\begin{tabular}{|l|l|l|l|l|}
\hline \multicolumn{6}{|c|}{ Table VI: Immunological functioning } \\
\hline \multicolumn{7}{|c|}{ CD4+ cell counts } \\
\hline BDI Scores & $>500$ & $351-500$ & $200-350$ & $<200$ \\
$<14$ & $0(0 \%)$ & $1(5.8 \%)$ & $1(4.1 \%)$ & $0(0 \%)$ \\
$14-30$ & $1(33.3 \%)$ & $12(70.5 \%)$ & $12(50 \%)$ & $9(45 \%)$ \\
$31-45$ & $2(66.7 \%)$ & $3(17.6 \%)$ & $10(41.6 \%)$ & $11(55 \%)$ \\
$46-63$ & $0(0 \%)$ & $1(5.8 \%)$ & $1(4.1 \%)$ & $0(0 \%)$ \\
\hline Total & 3 & 17 & 24 & 20 \\
\hline
\end{tabular}

number of factors were independently associated with depression in HIV/AIDS.

Multivariate analysis was used for the independent effect of factors associated with major depression among the HIV-positive patients. All the factors that had been found statistically significant with depression among HIV patients at bivariate analysis were included in the multivariate regression model to assess their independent association. The factors found to be independently associated with depression in HIV/AIDS were suicidal ideation, psychomotor retardation, WHO stage III,

\section{Table VII: WHO staging and severity of depression.}

\begin{tabular}{|l|l|l|l|l|l|}
\hline BDI score & \multicolumn{1}{l|}{ WHO STAGE } \\
\hline BDI scores & WHO In (\%) & WHO II $n(\%)$ & WHO III $n(\%)$ & \multicolumn{1}{l|}{ WHO I V n(\%) } & TOTAL \\
$<14$ & $2(25 \%)$ & $1(4.5 \%)$ & $1(3.4 \%)$ & $0(0 \%)$ & $4(6.3 \%)$ \\
$14-30$ & $4(50 \%)$ & $13(59.1 \%)$ & $11(37.9 \%)$ & $5(100.0 \%)$ & $33(51.6 \%)$ \\
$31-45$ & $2(25 \%)$ & $7(31.8 \%)$ & $16(55.2 \%)$ & $0(.0 \%)$ & $25(39.1 \%)$ \\
$46-63$ & (0\%) & $1(4.5 \%)$ & $1(3.4 \%)$ & $0(.0 \%)$ & $2(3.1 \%)$ \\
\hline TOTAL & 8 & 22 & 29 & 5 & 64 \\
\hline
\end{tabular}


Table VIII: MMSE scores in the study patients, by HIV status

\begin{tabular}{|l|l|l|l|l|l|}
\hline Characteristic & HIV-Positive N=64 $n(\%)$ & HIV-Negative N=66 $n(\%)$ & $X^{2}$ & OR (95\%Cl) & $P$-Value \\
\hline No impairment & $19(29.7 \%)$ & $32(48.5 \%)$ & 4.81 & $0.44(0.22-0.92)$ & 0.029 \\
\hline Impairment & $45(70.3)$ & $34(41.5 \%)$ & & & \\
\hline
\end{tabular}

\section{Table IX: Factors associated with depression in HIV-positive patients.}

\begin{tabular}{|c|c|c|c|c|c|}
\hline Variable & $B$ & SE & OR & $95 \% \mathrm{Cl}$ & $P$-value \\
\hline $\begin{array}{l}\text { Suicidal ideation } \\
\text { Psychomotor retardation } \\
\text { WHO stage III } \\
\text { Marital status (Co-habiting) } \\
\text { History of mental illness in family } \\
\text { Constant }\end{array}$ & \begin{tabular}{|l|}
6.18 \\
3.21 \\
4.24 \\
3.91 \\
-1.82 \\
-4.81
\end{tabular} & $\begin{array}{l}1.56 \\
2.81 \\
1.74 \\
1.71 \\
0.79 \\
2.206\end{array}$ & $\begin{array}{l}486.9 \\
68.70 \\
69.07 \\
49.89 \\
0.162\end{array}$ & $\begin{array}{l}22.47-10553 \\
5.11-922 \\
2.30-2074 \\
1.75-1415.8 \\
0.03-0.773 \\
0.029\end{array}$ & $\begin{array}{l}<0.001 \\
0.001 \\
0.015 \\
0.022 \\
0.022\end{array}$ \\
\hline
\end{tabular}

cohabiting, and family history of mental illness. However, the very wide confidence intervals (22.47-10553) for suicidal ideation presents a limitation in interpreting this result, putting into question the validity of this finding. Parameters of sadness, sleep loss, guilt, loss of interest, appetite, and weight changes, low energy levels or indecisiveness were not associated with depression in HIV/AIDS. (Table IX)

\section{Discussion}

Findings from this study show that there are differences in the clinical features between HIV-positive and HIVnegative depressed patients. This study was able to demonstrate that HIV-positive patients were more likely to be widowed and older. HIV-positive patients were less likely to have a family member with a mental illness and have later onset of depressive illness. Symptomatically, compared to HIV-negative patients, HIV-positive patients were more critical of themselves; had more problems making decisions; had poorer sleep and felt more easily tired and more had cognitive impairment. Low CD4 counts were not significantly associated with depression. The study limitations include the fact that it was conducted in hospital settings and may thus be subject to bias. Recall bias as far as history of previous and family history of mental illness may also affect the results. The MMSE is not a sensitive tool for subcortical cognitive deficits as seen in HIV-positive patients. The sample size is relatively small compared to other studies that generally had samples of more than 300 patients. This may have impacted on the multivariate analysis, which had very wide confidence intervals. Studies with larger sample sizes need to be conducted.

\section{Socio-demographic characteristics}

Compared to HIV-positive patients, HIV-negative patients were younger, had an earlier onset of depression, were less likely to be widowed and were more likely to be employed. The socio-demographic findings of older age and later onset of depression among the HIV-positive patients suggest HIV as being an aetiological factor in their depression. ${ }^{18}$ The differences seen clinically may also be due to the fact that the older HIV-positive patients had gone through numerous life events such as divorce and loss of partners to HIV/AIDS. The older people are, the more life events they experience and this could explain the statistical significance we have in this study. Findings showed a generally young age of patients (<30years) which may be explained by the low life expectancy in Uganda and Sub-Saharan Africa as a whole. The majority of the population are predominantly youthful with HIV/AIDS ravaging this particular segment of the population. ${ }^{1,2}$ These findings are however different from those in America and Europe where there is a greater representation of older people in such studies.

Depression associated with HIV may therefore be acquired and secondary to HIV/AIDS and different from the primary depression in HIV-negative patients. Indeed secondary affective disorders in HIV/AIDS have been reported in other studies. ${ }^{6}$

The findings of HIV-positive depressed patients being widowed has previously been reported. 7,19 Such losses may cause bereavement and lead to diminished support. Patient bereavement complicating depression is not unusual in HIV/AIDS and could have negative consequences by exacerbating depression worse. ${ }^{7}$ There was a high rate of unemployment among the HIV-positive patients. Unemployment could possibly be a consequence of HIV disease severity. Unemployment has also been known to compound depression. ${ }^{9}$

\section{General patient characteristics}

The HIV-positive patients were less likely to have a family member with a mental illness, were more likely to have had a medical illness before onset of depressive symptoms and were more likely to have been taking 
medicines before onset of depressive symptoms. The finding that HIV-positive patients were less likely to have a family member with mental illness makes it unlikely that genetic predisposition played a role in aetiology. Similar conclusions have been reached in other studies of HIV related mood disorders. ${ }^{10,34}$

HIV-positive patients also were more likely to have had a medical illness before onset of depressive symptoms and also to have been taking medicines before onset of symptoms. This particular finding was unique to this study. It may mean that HIV-positive patients were attempting to self medicate using non-prescribed over the counter medications for the symptoms that had not been identified by other practitioners before getting psychiatric help. Depressive symptoms in HIVinfection have been reported to manifest up to 1.5 years before onset of AIDS. ${ }^{11,10}$

Medical illness as the probable cause of depression was ruled out by carrying out a complete physical examination and blood tests. Patients with an active medical condition, other than HIV/AIDS, were excluded from the study. It is therefore more likely that these patients were unlikely to be receiving medications for a diagnosable medical illness but rather, they were more likely to be self-medicating for somatization. Indeed somatization has been widely documented in the symptom presentation of depression in Africa. ${ }^{8,21}$ It is therefore possible that these patients were suffering numerous somatization symptoms as indicators of psychological distress before onset of their major depression.

\section{Clinical characteristics}

HIV-positive depressed patients differed from their HIVnegative counterparts for the parameters of sleep and appetite disturbance. The findings of sleep were in keeping with previous studies. ${ }^{3,11}$ However unlike these studies ${ }^{3,11}$ our HIV-positive patients had fewer appetite disturbances. The explanation for this finding is not clear.

Previous research has documented an increase in suicidal ideation and suicide attempts in HIV-positive patients. ${ }^{12,22}$ This was not the case in the current study probably suggesting more family support for our HIV-patients compared to studies undertaken in developed countries. Nevertheless, using multivariate analysis, suicidal ideation was found to be independently associated with depression in the HIV positive patients. This compares to other findings in the literature.

The findings from the 9 diagnostic items of MINI alluded to the fact that the other core depressive symptoms of sadness and loss of interest were not different in the HIV-positive and HIV-negative group which is similar to previous studies that studied depression in HIV-positive populations. 3,23,24,25,26 Indeed the mean BDI scores were similar between the two groups. Previous studies have also shown no significant differences in the severity of mood symptoms between HIVpositive and HIV-negative subjects. ${ }^{27}$

However on the BDI, HIV positive patients were more likely to have sleep problems, fatigue, be self-critical and have problems making decisions. These are core symptoms of depressive illness and they seemed to have been more pronounced in the HIV-positive patients demonstrating that this group to be more profoundly disturbed than the HIVnegative group.

We found no studies in the literature that compared core individual symptoms of depression between HIV-negative and HIV-positive patients. Musisi et al in a previous Ugandan study compared depression rates in HIV-positive patients with and without pulmonary tuberculosis (PTB). ${ }^{28}$ In that study, depression was found to be more severe in HIV-positive patients with PTB and the depression was associated with more guilt, suicide ideation and feelings of worthlessness. The present study excluded any physical illnesses associated with the HIV but still found more greater depressive disturbances in HIV-positive patients.

\section{Immune function}

There was no significant association between the CD4+ levels and severity of depression in our study and no association with increasing severity of HIV stage. This is in keeping with previous studies that have reported that CD $4+$ cell counts may not be associated with measures of severity of depression. ${ }^{29}$ Indeed in previous studies, the association between depression and immune function, particularly CD4+ T lymphocyte counts, reported varying findings with some showing an association and others not. ${ }^{20,23,25,26,30}$ A possible explanation from our finding is that depressive symptoms have been reported to occur up to 1.5 years before the AIDS diagnosis. ${ }^{10}$ It is therefore possible that our HIV-positive patients had their depressive symptoms earlier, before onset of manifest severe AIDS and thus we may have assessed them in this period. Indeed most of our patients were in stage II and III of their HIV/AIDS illnesses.

\section{Cognitive function using the MMSE}

The HIV-positive depressed patients had significantly more cognitive impairment compared to the HIV-negative depressed patients. This could be a result of the direct central nervous system effects of HIV. ${ }^{18}$ Other studies have suggested an association between HIV-related neuropsychiatric disorders and HIV-associated cognitive dysfunction or dementia. ${ }^{31}$

The MMSE is not sensitive for identifying subcortical cognitive impairment, which is the case among HIVpositive patients. ${ }^{24}$ However, that it was able to detect these changes means the impairment in our HIV-positive patients could actually be worse than reported in our findings.

Depression itself can cause cognitive pseudodementia. However the rates for this should have been the same in both HIV positive and HIV-negative groups as their BDI scores were similar. It is worth noting that there were no significant correlations between the MMSE and the BDI scores in terms of severity of both conditions. This finding is similar to previous studies ${ }^{31}$ that found no significant dysfunction in neuropsychological performance among HIV-positive asymptomatic patients. ${ }^{31}$

\section{Factors associated with depression in HIV/AIDS: Multivariate analysis} Using multivariate analysis, it was found that our HIVpositive depressed patients with depression were more likely than HIV-negative depressed patients to have suicidal ideation, psychomotor retardation, be cohabiting, have a negative family history of mental illness and to be 
in WHO stage III. The findings of suicide being associated with depression in HIV/AIDS are supported by previous studies both locally and internationally. ${ }^{12,13}$ Suicide is common in HIV/AIDS and this finding has clinical implications in the management of HIV/AIDS. Depressed patients with HIV/AIDS should be routinely assessed for suicide risk. Findings of more severe psychomotor retardation in HIV-related depression have also been reported in previous studies. ${ }^{3,11}$ In this study this may explain the poor performance on the MMSE and the indecisiveness seen on the BDI.

Previous studies have reported marriage as being protective against depression; and that being single, divorced, and widowed is associated with depression and suicide risk. ${ }^{7}$ Many of our HIV-positive patients had lost a partner to HIV/AIDS and the majority had no partners.

The fact that having a family history of mental illness was not associated with depression in the HIV-positive patients may point to HIV being an aetiological factor as an acquired trait with the depression being secondary to HIV/AIDS. ${ }^{32}$

In our study, HIV stage III was associated with depression. This suggests that psychiatric illness, including depression is more likely to develop in late HIV disease. ${ }^{33}$ The HIV-positive patients were significantly older and developed depression later, again suggesting that HIV may be of aetiological importance in late onset depression in this group. 32 The clinical implication of this finding is that clinicians should screen for depression among all HIV-positive patients, especially in late stage HIV/AIDS. Also these findings do suggest routine HIVtesting in all patients presenting with late onset depression in highly endemic HIV areas like Uganda.

\section{Conclusion}

This study showed that HIV-related depression is clinically different from the depression found in HIV-negative patients. It appears to be acquired and therefore a secondary depressive illness as opposed to the genetically driven primary affective depressive disorder of HIV-negative patients. This requires further study. The HIV-related depression was characterized by negative family history of mental illness, use of medication for treating an illness other than depression, older age of the patients, older age of onset of the depression and cognitive impairment. Compared to HIV-negative patients, HIV-positive patients were more critical of themselves, had problems with decision making, had more sleep and more appetite disturbances. They also felt more fatigued with significant cognitive impairment. These findings call for routine screening for depressive illnesses in all HIVinfected individuals especially in late onset depressive illness and in populations highly endemic for HIV/AIDS as well as for effective treatment of the depression of HIV/AIDS and its associations.

\section{References}

1. WHO and UNAIDS: Global initiative to provide antiretroviral therapy to 3 million people with HIVIAIDS in developing countries by the end of 2005, World Health Organization, Geneva. 2003.
2. WHO: World Health Organization Publications, World Health Organization Publications, Geneva. 2005.

3. Norton J. The Neuropsychiatric Symptoms of AIDS. Am J Psychiatry 2000; 157:2059-2060.

4. American Psychiatric Association, (2000) Diagnostic and Statistical Manual of Mental Disorders text Revised, 4th Edition (DSM -IV -TR), APA Press.

5. Sherbourne CD, Hays RD, Fleishman JA, et al Impact of Psychiatric Conditions on Health-Related Quality of Life in Persons With HIV Infection, Am J Psychiatry 2000; 157:248-254.

6. Folstein MF, Folstein SE, Mc Hugh P. Mini Mental State A practical method for grading the cognitive function state of patients for the clinician. J Psychiatric Residence 1975, VOL 12:189-198.

7. Komiti A. Depression in people living with HIVIAIDS attending primary care and outpatient clinics. Austral N Z J Psychiatry 2003; 37(1): 70-7.

8. Patel V. Explanatory models of mental illness in Sub-Saharan Africa. Soc Sci Med1 995; 40(9) 1291-1298.

9. Rosack J. Depression Most Costly Illness for Employers, Psychiatric News 2003; 38 (14).

10. Lyketsos CG, Hoover DR, Guccione $M$ et al. Changes in depressive symptoms as AIDS develops. The Multicenter AIDS Cohort Study. Am J Psychiatry 1996; 153:1430-1437.

11. Halman M: Management of depression and related neuropsychiatric symptoms associated with HIVIAIDS and antiretroviral therapy: Can J Infect Dis 2001; 12 (Suppl C): 20C30C.

12. Stern RA, Perkins DO, Evans DL. Neuropsychiatric Manifestations of HIV-1 Infection and AIDS, Neuropsychopharmacology. The Fifth Generation of Progress pp 1281-1300.

13. Cruess DG, Douglas SD, Petitto JM et al. Association of Resolution of Major Depression With Increased Natural Killer Cell Activity Among HIV-Seropositive Women. Am J Psychiatry 2005; 162:2125-2130.

14. Sacks M, Burton W, Dermatis H, Looser-Ott S, Perry S. HIV related cases among 2094 admission. Indian J Med 1995; 121; 451-467.

15. U.S. Department of Health and Human Services. Treatment of Major Depression. Clinical Practice Guideline, U.S. Department of Health and Human Services, Public Health Service, Agency for Health Care Policy and Research. 1993; Publication 2 (5) 930551.

16. Horberg MA, Silver M J, Hurley LB. Effects of depression and selective serotonin reuptake inhibitors use on adherence to HAAR and clinical outcomes in HIV-Infected patients. J AIDS 2008;47:337-339.

17. Kaplan and Saddock's Synopsis of Psychiatry, Behavioral Sciences /Clinical Psychiatry, 9TH Edition, Lippincott Williams \&Wilkins 1998.

18. Evans DI, ten Have TR, Douglas SD, et al. Association of Depression With Viral Load, CD8 T Lymphocytes, and Natural Killer Cells in Women With HIV Infection. Am J Psychiatry 2000; 159:1752-1759

19. Maling S, Grosskurth H, Musisi S. HIV infection among first time admission patients with severe mental illness at Butabika and Mulago Hospitals. Proceeds from Makerere University, Faculty of Medicine, First Annual Scientific Conference 24-26 November 2005 Entebbe Uganda.

20. Evans EDL, Leserman J, Perkins DO, et al. Stress-associated reductions of cytotoxic T lymphocytes and natural killer cells in 
asymptomatic HIV infection. Am J Psychiatry 1995; 152:543-550.

21. Okello ES, Neema S. Explanatory Models and Help-Seeking Behavior: Pathways to Psychiatric Care Among Patients Admitted for Depression in Mulago Hospital, Kampala, Uganda Qual Health Res 2007; 17; 14.

22. Ruiz P. Living and Dying With HIVIAIDS: A Psychosocial Perspective. Am J Psychiatry 2000; 157:110-113.

23. Rabkin JG, Williams JB, Remien RH, et al. Depression, distress, lymphocyte subsets, and human immunodeficiency virus symptoms on two occasions in HIV-seropositive homosexual men. Arch Gen Psychiatry 1991; 48:111-119.

24. Ruiz P, Langrod JG. Hispanic Americans, In Substance Abuse: A Comprehensive Textbook, 3rd ed, 1997; Lippincott Williams. pp 705-711

25. Leserman J, Petitto JM, Perkins DO, et al. Severe stress, depressive symptoms, and changes in lymphocyte subsets in human immunodeficiency virus-infected men: a 2-year follow-up study. Arch Gen Psychiatry 1997; 54:279-285

26. Perry S, Fishman B, Jacobsberg L, Frances A: Relationships over 1 year between lymphocyte subsets and psychosocial variables among adults with infection by human immunodeficiency virus. Arch Gen Psychiatry 1992; 49:396-401.

27. Perkins DO, Stern RA, Golden RN et al: Mood disorders in HIV infection: prevalence and risk factors in a nonepicenter of the AIDS epidemic. Am J Psychiatry 1994; 151:233-236.

28. Musisi S, Nakasujja N, Zziwa S. Depression among HIV/TB cormobidity in Mulago hospital. Proceedings of the second annual faculty of medicine scientific conference; Munyonyo, Uganda, Sept 7th - 9th 2006

29. Judd F, Komiti A, Chua P. Nature of depression in patients with HIVIAIDS. Austral N Z J Psychiatry 2005; 39:826-832.

30. Burack JH, Depressive symptoms and CD4 lymphocyte decline among HIV-infected men. JAMA 1993; 270:2567-2573.

31. Bornstein RA, Pace P, Rosenberger P, et al. Depression and neuropsychological performance in asymptomatic HIV infection. Am J Psychiatry 1993; 150, 922-927.

32. Jacobson JL Jacobson SW. Neurological, Psychiatric, and Developmental Disorders; Meeting the Challenge in the Developing World, Institute of Medicine. The National Academies Press 2001.

33. Kinyanda E. Frequency with which psychiatric disorders are associated with a positive HIV-1 serostatus as seen in persons attending a TASO clinic in Mulago; Dissertation submitted in partial fulfillment for the award of a masters degree of medicine in psychiatry of Makerere University, 1998

34. Nakimuli-Mpungu E, Musisi S, Kiwuwa Mpungu S, Katabira E. Primary Mania Versus HIV-Related Secondary Mania in Uganda. Am J Psychiatry 2006;163:1349-1354 